\title{
Comparative Severity Analysis of Asian Soybean Rust in Soybean Farms Sown in December and February in Mato Grosso, 2018/19 Growing Season
}

\author{
Erlei Melo Reis ${ }^{1}$, Rodrigo Marcelo Pasquali ${ }^{2}$, Luana Maria de Rossi Belufi ${ }^{2}$, Wanderlei Dias Guerra ${ }^{3}$ \\ \& Mateus Zanatta ${ }^{1}$ \\ ${ }^{1}$ Instituto AGRIS, Passo Fundo, RS, Brazil \\ ${ }^{2}$ Fundação de Pesquisa e Desenvolvimento Tecnológico Rio Verde, Lucas do Rio Verde, MT, Brazil \\ ${ }^{3}$ Aprosoja-Rua Eng, Centro Político Administrativo, MT, Brazil \\ Correspondence: Erlei Melo Reis, Instituto AGRIS, Rua Miguel Vargas, 291 Passo Fundo, RS, CEP: 99025-380, \\ Brazil. E-mail: erleireis@upf.br
}

Received: June 7, 2020

Accepted: July 15, $2020 \quad$ Online Published: August 15, 2020

doi:10.5539/jas.v12n9p130

URL: https://doi.org/10.5539/jas.v12n9p130

\begin{abstract}
The objective of this work was to compare the leaflet severity of Asian soybean rust in farms sown in December and February in the state of Mato Grosso. In the survey, 28 fields were sampled in 14 counties in the North, West and South regions of the state. A total of 40 leaflets were collected per plot, in randomized treatments with four replication and three crop phenological stages. Leaflet severity was assessed according to a diagrammatic scale. The data were expressed as leaflet severity, submitted to linear regression analysis, calculated the area under the disease progress curve (AUDPC) considering the three phenological stages sampled, and the means compared by the Tukey's test. Leaflet severity was significantly higher in the fields sown in December than in February, as well the number of fungicides sprayings. Our results indicate that the proposed change in seeding time from December to February can be implemented by significantly reducing risks and in compliance with the principles of IN 002/2015.
\end{abstract}

Keywords: Phakopsora pachyrhizi, Glycine max, sowing time, soybean free-period

\section{Introduction.}

In Brazil, Asian soybean [Glycine max (L.) Merr.] rust (ASR) caused by the basidiomycete fungus Phakopsora pachyrhizi Sydow \& Sydow (1914) is the main crop disease (Godoy et al., 2016). Damage caused by a plant disease is the basic tool to justify whether control is needed or not but it should be scientifically determined. For ASR, the damage can be estimated based on the functions reported by Danelli et al. (2015) and depending on its severity it can be as high as $80 \%$.

ASR control measures include elimination of volunteer plants, observation of a 60-90-day soybean-free period in the off-season, cultivation of early cultivars sown at the beginning of the recommended season, and use of cultivars with partial resistance and chemical control. However, fungicides are still the main measure for its control (Reunião de Pesquisa da Soja da Região Sul, 2012).

The state of Mato Grosso MT) is the largest soybean producer in the country with a grown area in the 2018/19 growing season of 9,756,668 hectares (IMEA, 2019). Sowing is authorized from September $16^{\text {th }}$ and is concentrated in October and November.

There is a demand from growers to produce their own seeds to be legally authorized at another time, suggesting the month of February in an area of approximately 20 to 30 thousand hectares.

Most of the seeds produced in the state originate from crops sown during the normal season (October/November), usually in regions with higher altitude and a more favorable environment for seed production and conservation during storage. However, due to adverse environmental conditions, many growers, and, seed producing companies, are not always able to produce seeds in quantity and/or quality according to current legislation, considering that sowing can only be done until December $31^{\text {th }}$, the last date to complete seed production. The sowing carried out in February coincides with the time when most of the soybean fields in the surrounding areas 
have already been, or are being harvested, and in the reproductive stage, there are few fields remaining from normal season. As a result, there is a reduction in the P. pachyrhizi inoculum in the fields cultivated at this time compared to December.

In December sown soybean (DSS), the severity of ASR has been high, sometimes requiring even more than 10 fungicides sprayings and yet with low efficiency. The soybean cultivation at a time when the environment is less favorable for the ASR development, the month of February is the one that has always been used by growers, even before the existence of the soybean free-period. This expansion in the period of the soybean crop presence in the field due to the February sown does not mean that it will enter the soybean-free-period.

No publications were found in the available literature that scientifically justified avoiding soybean cultivation in February. Nevertheless, Moreira et al. (2015) in conducted work in Lucas do Rio Verde county, MT state, studied the temporal dynamics of soybean rust in soybean cultivars of different maturity groups, but not focusing on ASR intensity in December and February sowing time.

The objective of the study was to evaluate and compare the foliolar severity of ASR in soybean fields sown in the months of December 2018 and February 2019 in the state of Mato Grosso.

The hypotheses formulated in this work are that (a) the soybean crops sown in December are more severely attacked by ASR than those sown in February and (b) receiving a greater number of fungicide applications.

\section{Method}

The survey was carried out in farms in the North, West and South regions of the state, sown in the months of December 2018 and February 2019 with a regional difference in environment and disease management.

The evaluations were carried out from January to May 2019, during the entire crop cycle in the two sowing times.

During the first visit, data were recorded regarding the county, farm name, producer name, soybean cultivar, sowing date, crop phenological stage, geographical coordinates of each sampling point and subsequently the sanitary management carried out by growers.

The rust detection and initial leaflet sampling were made by Aprosoja team previously trained and sent for analysis in the laboratory of the Rio Verde Foundation for Research and Technological Development, Lucas do Rio Verde-MT (FRV). After the disease was detected by the FRV laboratory, the sampling was performed by an FRV team.

In each trial, four sampling repetitions were identified with fiberglass shafts and solid white plastic flags, each with approximately $25 \mathrm{~m}^{2}$ and with a minimum distance of 100 meters between them. Two sub-plots were marked in each experimental unit. Two leaflets were removed from each of ten plants at totaling 40 leaflet per sampling.

With the crop phenology evolution and the petioles drop of the lower nodes, in the DSS, the leaflets present in the upper nodes and in the cycle final stage, were collected. Samplings were carried out initially every fifteen days, and according to the development of severity, in DSS, the interval between collections had to be reduced, since with the high severity of the disease began to cause leaves fall.

In the samples collected, the severity of leaflets was estimated at the Plant Pathology Laboratory of the Rio Verde Research and Technological Development Foundation according to the diagrammatic scale for Asian soybean rust according to Godoy et al. (2006). The analysis was always done by the same personnel.

The experimental design was randomized treatments with four replications. With the data, the areas under the disease progress severity curve (AUDPC) were calculated and the averages means by the Tukey test for the areas sown in December and February of each region.

The sampling work was carried out in fields that received their own rust control program with commercial fungicides without any interference from the monitors regarding the fungicides used and the moments of their application, including pest control. The list of treatment programs used in each crop was later sent to the FRV by the producers in the sampled areas.

\section{Results and Discussion}

The work covered 28 fields, 17 sown in December and 11 in February, located in 14 counties in the North, West and South regions, the main soybean producers in MT: counties names and number of fields grown in December: North (Claudia, Nova Mutum, Lucas do Rio Verde), West (Campos de Júlio, Campo Novo do Parecis, Sapezal) and AUDPC rated by leaflet rust severity in three soybean phenological, sown in December and February in the 
North (MT) region, shows a more accentuated evolution of ASR in DSS than in February sowing (DSS) (Figure 1).

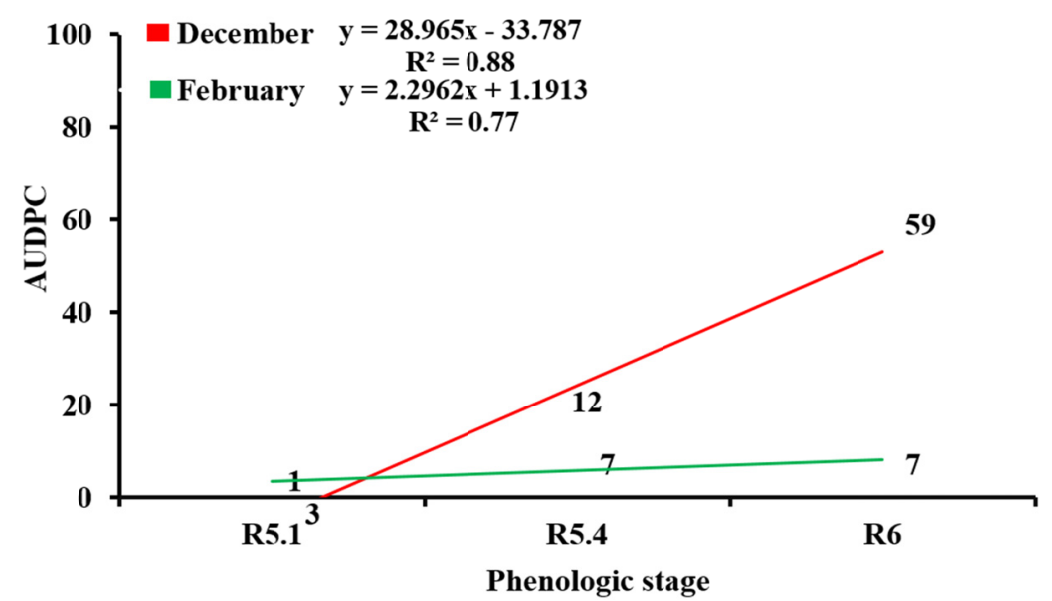

Figure 1. Comparison of the AUDPC rated by leaflet rust severity in three phenological stages of soybean crop, sown in the months of December and February in the Northern region (MT)

The AUDPC rated by rust severity totaled 72 units in the December sown plots, whereas in February only 17 units (Figure 2).

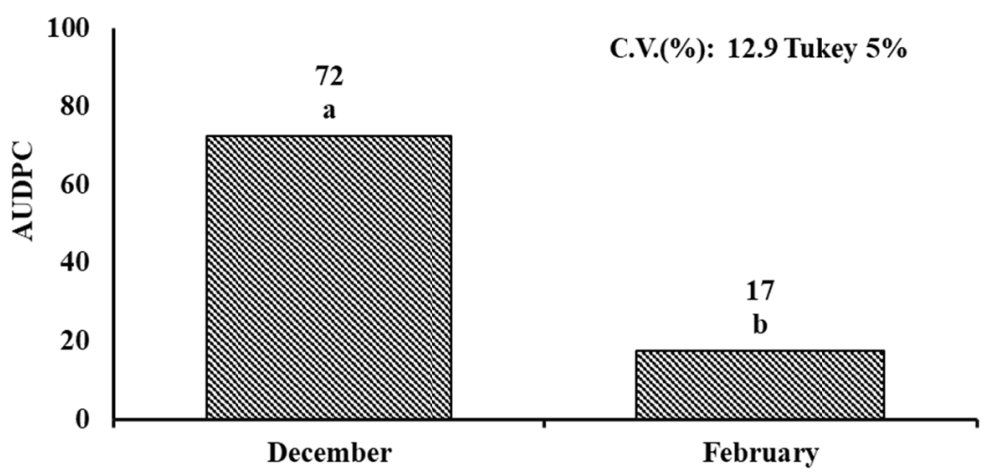

Figure 2. Comparison of areas under the progress curve of leaflet rust severity in Asian rust (AUDPC), in soybean fields sown in December and February in the Northern region (MT). Means followed by the same letter are similar by the Tukey test at $5 \%$

The AUDPC, as linear progress, of foliolar severity of soybean rust in three phenological stages of soybean crop, sown in the months of December and February in the southern region (MT), means of seven fields located in three counties showed even more marked progress in December sowing than in February (Figure 3). 


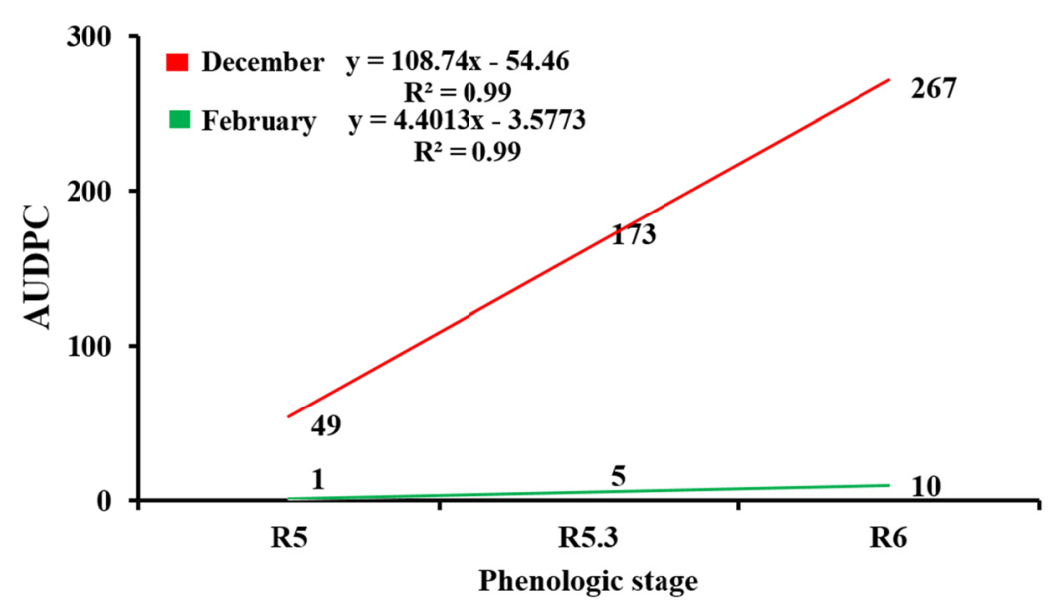

Figure 3. Linear progress of AUDPC rated by leaflet rust severity in three phenological stages in soybean crop, sown in months of December and February in the Southern region (MT)

The AUDPC rated by rust leaflet severity totaling 489 units in December, whereas in February only 16 units (Figure 4).

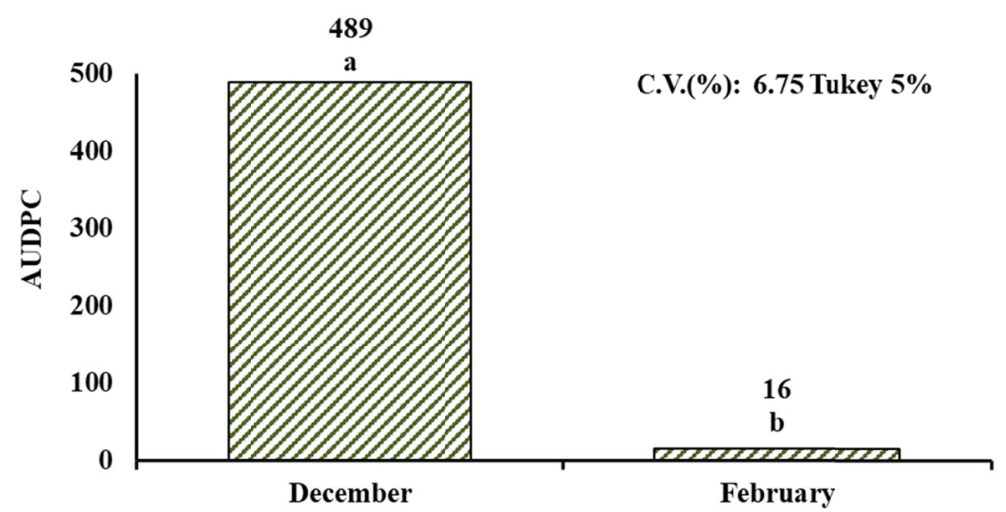

Figure 4. Comparison of the areas under the leaflet rust severity curve of Asian rust (AUDPC), in soybean crops sown in December and February in the Southern region (MT). Means followed by different letters are similar according to Tukey test at $5 \%$

In the Western region, only commercial fields DSS were sampled due to the lack of areas sown in February. Also, the fields of Sapezal and Campos de Júlio, due to their high severity, resulting in defoliation, only leaflets from the upper nodes were collected (Figures 5 and 6). The highest rust severity among all assessed fields in our work was detected in this region with 694 AUDPC units (Figure 6), indicating that this region was more critical for ASR severity for December than February. In this region seed companies, that sown in December, are more concentrated than in other regions. The traditional seed producing region in MT are in the Southern region. 


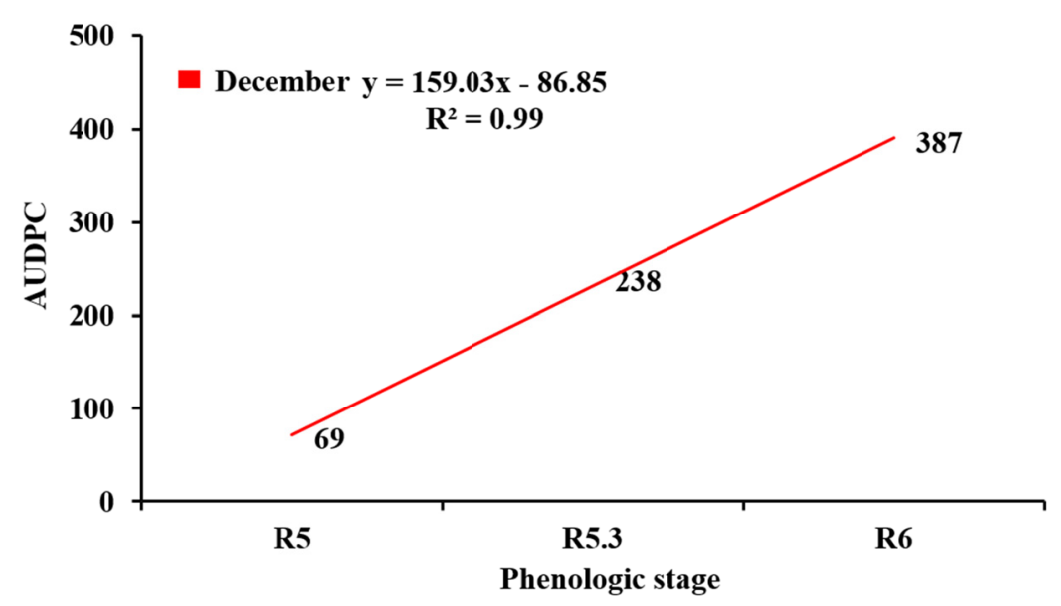

Figure 5. Linear progress of AUDPC rated by leaflet rust severity in three phenological stages in soybean crop, sown in December in the Western region (MT)

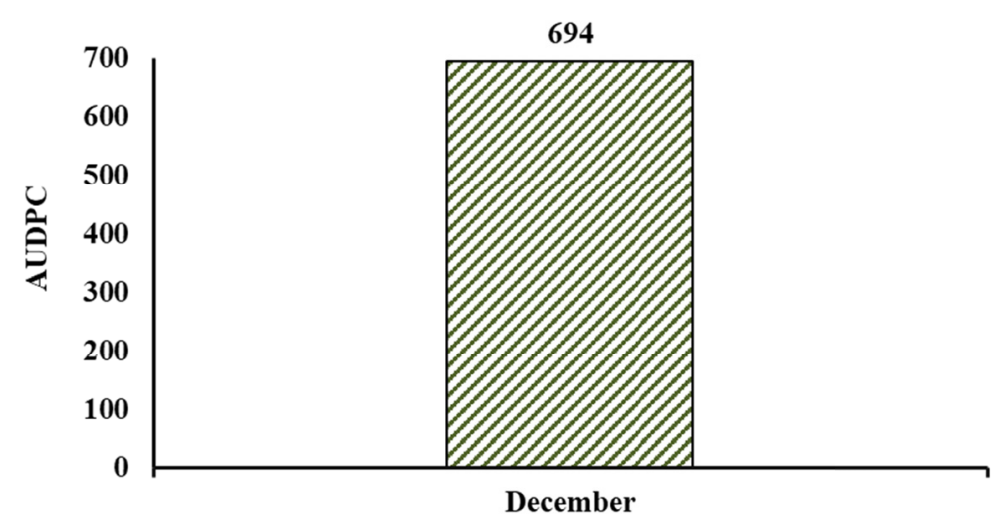

Figure 6. Area under the AUDPC rated by leaflet severity of soybean rust sown in December in the Western region (MT)

The defoliation of soybean caused by ASR begins when the density of symptoms/signs reaches $57.4 / \mathrm{cm}^{2}$ or 4,248.4/leaflet. The symptoms/signs are concentrated in the leaflets inserted in the 5th, 6th, and 7th nodes, diluting in the upper ones (Reis et al., 2020). This is due to the longer exposed time to spore deposition, less light intensity that allows greater spore germination (Blum et al., 2015), longer leaf wetness duration (Reis et al., 2004), less solar radiation and less wind intensity.

The difference in rust severity between the two seeding times may be due to the frequency and rainfall volume (Del Ponte et al., 2006). The comparison of historical rainfall (Figures 7, 8 and 9) per decade, in the period from 1995 to 2018, shows less rain frequency and volume accumulated during the soybean cycle sown in February, especially in April. It is noteworthy that in the beginning of 2019, for the three sampled regions, the rainfall was higher throughout the state than the average of the last 24 years, but still, the severity of rust in February seeded crops in the South and North regions was much smaller than in the December sown crops in the same region, indicating that the same would occur in the February crops that may have occurred in the western region. The hypothesis for this greater severity in December sowing is that the plants grow faster, and the requirements for infection a minimum of 6-7 hr of continuous leaf wetness (Melching et al., 1989) should be fulfilled. 


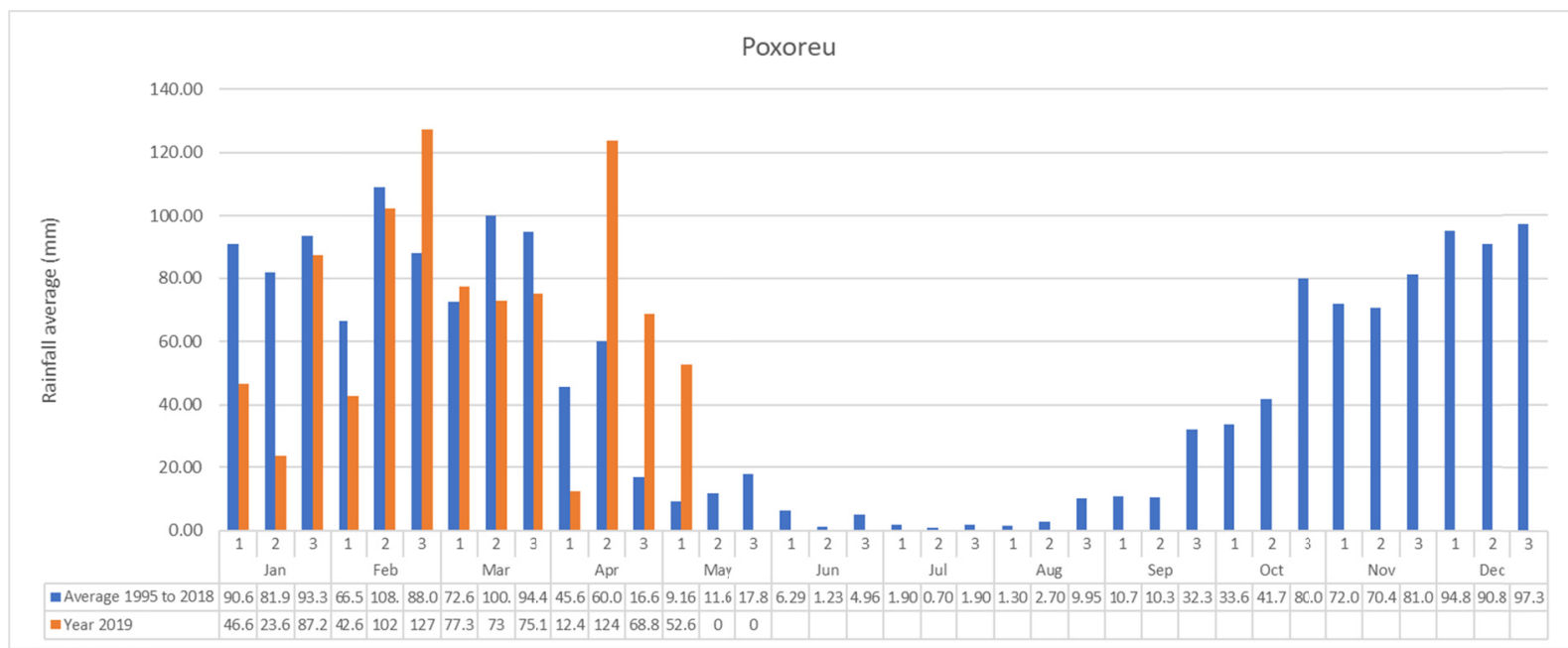

Figure 7. Mean rainfall (mm) per ten days period from January to May 2019, compared to 1995-2018 average at Poxoréu, MT. Source INMET (2019). The blue bars represent the decennial historical average, from 1995 to 2018 and the oranges the rainfall occurred in 2019, between the months January to May

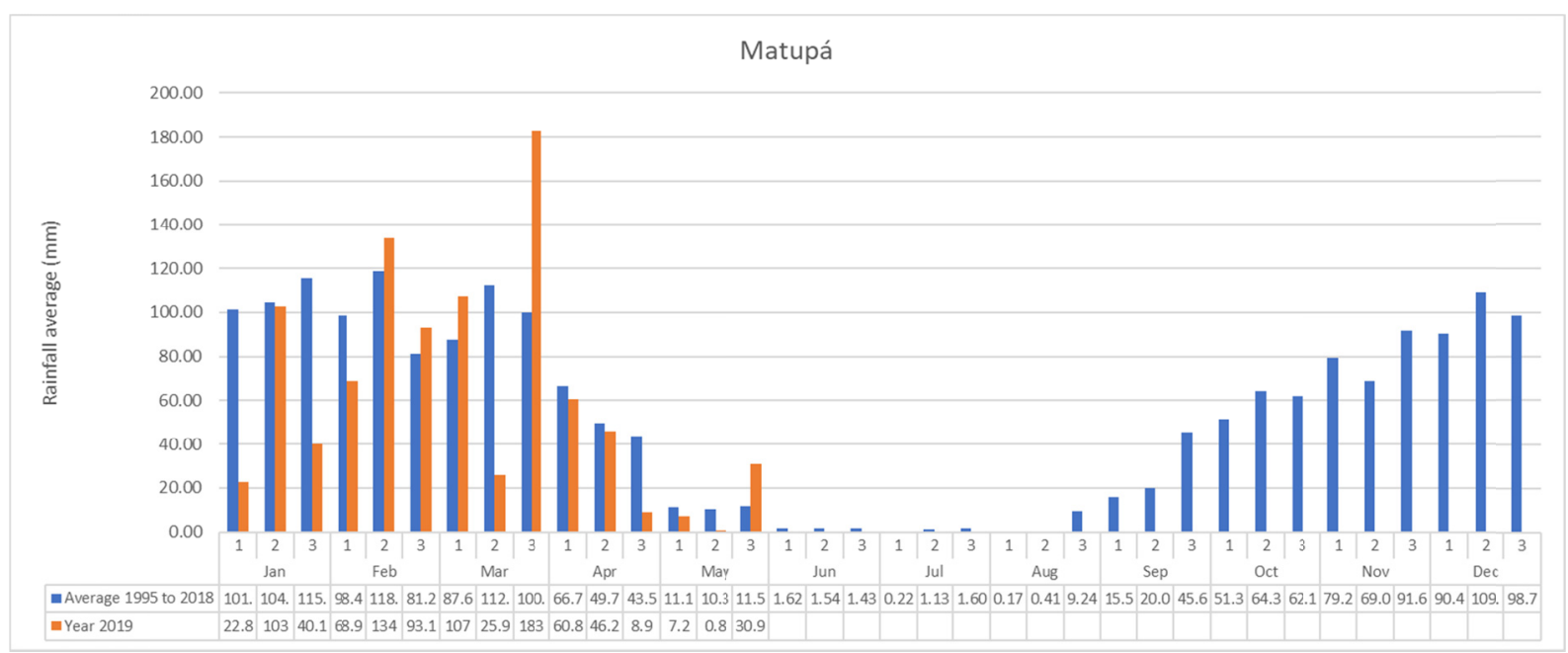

Figure 8. Mean rainfall (mm) per ten days period from January to May 2019, compared to 1995-2018 average at Matupá, MT. Source INMET (2019). The blue bars represent the decennial historical average, from 1995 to 2018 and the oranges the rainfall occurred in 2019, between the months January to May 


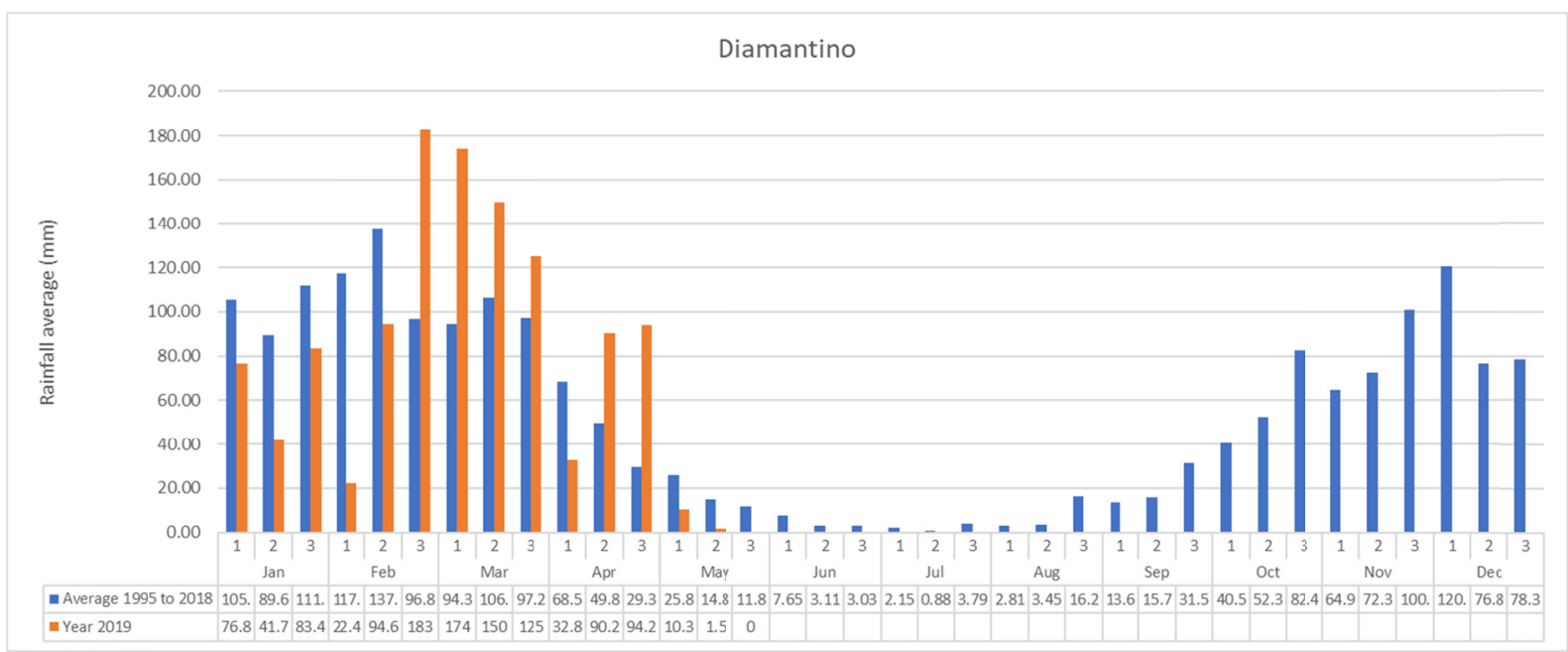

Figure 9. Mean rainfall (mm) per ten days period from January to May 2019, compared to 1995-2018 average at Diamantino, MT. Source INMET (2019). The blue bars represent the decennial historical average, from 1995 to 2018 and the oranges the rainfall occurred in 2019, between the months January to May

It is likely that the greatest historical frequency of rainfall during the soybean crop development in DSS, results in a greater number of infectious duration periods.

The continuous directional selection is taking place: (a) in the normal soybean season (September to December) through the use of site-specific fungicides (DMI, QoI, SDHI); (b) high number of sprayings per season 5.0/area/season; and (c) in the soybean weed plants in cotton crops area with more than one million hectares and mean of 7-8 sprayings/ha, especially of site-specific fungicides, generally of the same active ingredients used to control of P. pachyrhizi.

Our results indicate that the proposed change in seeding time from December to February can be implemented by significantly reducing risks and in compliance with the principles of IN 002/2015.

\section{References}

Blum, M. M. C., Reis, E. M., Francieli, T. V., \& Carlini, R. (2015). In vitro effect of substrate, temperature and photoperiod on Phakopsora pachyrhizi urediniospore germination and germ tube growth. Summa Phytopathologica, 41(2), 101-106. https://doi.org/10.1590/0100-5405/1999

Danelli, A. L. D., Reis, E. M., \& Boaretto, C. (2015). Critical-point model to estimate yield loss caused by Asian soybean rust. Summa Phytopathologica, 41(4), 262-269. https://doi.org/10.1590/0100-5405/2003

Del Ponte, E. M., Godoy, C. V., Li, X., \& Yang, X. B. (2006). Predicting severity of Asian soybean rust epidemics with empirical rainfall models. Phytopathology, 96, 797-803. https://doi.org/10.1094/PHYTO96-0797

Godoy, C. V., Koga, L. J., \& Canteri, M. G. (2006). Escala diagramática para avaliação da severidade da ferrugem da soja. Fitopatologia Brasileira, 31(1), 63-68. https://doi.org/10.1590/S0100-41582006000 100011

Godoy, C. V., Seixas, C. D. S., Soares, R. M., Marcelino-Guimarães, F. C., Meyer, M. C., \& Costamilan, L. M. (2016). Asian soybean rust in Brazil: past, present, and future. Pesquisa Agropecuária Brasileira, 51(5), 407-421. https://doi.org/10.1590/S0100-204X2016000500002

IMEA (Instituto Mato-grossense de Economia Agropecuária). (2019). Indicador Soja. Retrieved July 19, 2019, from http://www.imea.com.br/imea-site/indicador-soja

INMET (Instituto Nacional de Meteorologia). (2019). Retrieved July 22, 2019, from http://www.inmet. gov.br/portal

Ishii, H., \& Hollomon, D. W. (2015). Fungicide resistance in plant pathogens. Principles and a guide to practical management (p. 490). Springer, Tokyo. https://doi.org/10.1007/978-4-431-55642-8 
Melching, J. S., Dowler, W. M., Koogle, D. L., \& Royer, M. H. (1989). Effects of duration, frequency, and temperature of leaf wetness periods on soybean rust. Plant Disease, 73(2), 117-122. https://doi.org/ 10.1094/PD-73-0117

Moreira, E. N., Vale, F. X. R., Paul, P. A., Rodrigues, F. A., \& Jesus Júnior, W. C. (2015). Temporal dynamics of soybean rust associated with leaf area index in soybean cultivars of different maturity groups. Plant Disease, 99(9), 1216-1226. https://doi.org/10.1094/PDIS-10-14-1029-RE

Reis, E. M., Reis, A. C., \& Zanatta, M. (2020). Leaflet incidence to time the first fungicide application to control Asian soybean rust. Summa Phytopathologica, in press.

Reis, E. M., Sartori, A. F., \& Camara, R. K. (2004). Modelo climático para a previsão da ferrugem da soja. Summa Phytopathologica, 30(2), 290-292.

Reunião de Pesquisa da Soja da Região Sul. (2012). Indicações Técnicas para a Cultura da Soja no Rio Grande do Sul e em Santa Catarina, safras 2012/2013 e 2013/2014 (p. 142). XXXIX Reunião de Pesquisa de Soja, Passo Fundo RS, Embrapa Trigo.

Sydow, H., \& Sydow, P. (1914) A contribution to knowledge of parasitic fungi of the island of Formosa. Annales Mycologici, 12, 108.

\section{Copyrights}

Copyright for this article is retained by the author(s), with first publication rights granted to the journal.

This is an open-access article distributed under the terms and conditions of the Creative Commons Attribution license (http://creativecommons.org/licenses/by/4.0/). 